\title{
Note on conventions and list of abbreviations
}

Original spelling, capitalisation and punctuation have been retained in quotations from early modern printed and manuscript sources; closing punctuation has been supplied for display quotations with [square brackets] where not present in the original. Quotations from manuscripts sources are normally semi-diplomatic, unless otherwise noted. Corrections and interlineations are given within <angled brackets> and contractions expanded within [square brackets]. Deletions have not been transcribed or represented unless material to the argument. Place of publication for all texts printed before 1800 is London unless otherwise specified. Dates are Old Style throughout, though the calendar year is reckoned from 1 January, so adjustments have been made to years in respect of dates falling between 1 January and 24 March.

The following abbreviations are used throughout the volume:

\begin{tabular}{ll} 
Add. MS & Additional Manuscript \\
BL & British Library, London \\
Bodleian & Bodleian Library, Oxford \\
CA & The College of Arms, London \\
CCEd & The Clergy of the Church of England Database 1540-1835, \\
& www.theclergydatabase.org.uk \\
CSPD & Calendar of State Papers Domestic (London: Public Record Office) \\
CUL & Cambridge University Library \\
fol. (fols) & folio(s) \\
Folger & Folger Shakespeare Library, Washington DC \\
Gibson, Domestic & W. Gibson, A Social History of the Domestic Chaplain, 1530-1840 \\
\multicolumn{1}{c}{ Chaplain } & (London: Leicester University Press, 1997). \\
HMC & Historical Manuscripts Commission \\
Huntington & Huntington Library, San Marino, California \\
IELM & P. Beal, ed. and comp., Index of English Literary Manuscripts, \\
& Volume One: 1450-1625, 2 parts (London: Mansell, 1980); Volume \\
LMA & Two: 1625-1700, 2 parts (London: Mansell, 1987-93) \\
LPL & London Metropolitan Archives \\
NA & Lambeth Palace Library, London \\
ODNB & The National Archives, London \\
OED & The Oxford Dictionary of National Biography, www.oxforddnb.com. \\
sig. (sigs) & The Oxford English Dictionary, www.oed.com \\
SP & Signature(s) \\
$x$ & State Papers \\
&
\end{tabular}


STC

Wing
A.W. Pollard and G.R. Redgrave, A Short-Title Catalogue of Books Printed in England, Scotland, and Ireland and of English Books Printed Abroad 1475-1640, 2nd edn, rev. W. A. Jackson, F. S. Ferguson and K. F. Pantzer, 3 vols (London: The Bibliographical Society, 1976-91)

D. Wing, A Short-Title Catalogue of Books Printed in England, Scotland, Ireland, Wales and British America and of English Books Printed in Other Countries 1641-1700, 2nd edn, rev. and ed. T. Crist, J. J. Morrison, C. W. Nelson et al. (New York: Modern Language Association of America, 1988-98)

Names follow the spelling used in $O D N B$. All quotations from the ODNB follow the online edition; all online resources were accessed between July 2011 and June 2012. 
Hugh Adlington, Tom Lockwood, and Gillian Wright - 9781526110695 Downloaded from manchesterhive.com at 04/26/2023 01:30:26PM via free access 